\title{
ВЛАШКО У УСМЕНОМ ПРЕДАЊУ
}

\begin{abstract}
У раду се указује на ретке остатке успомена на печалбарење људи из пограничја источне Србије на велепоседима у Румунији (Влашкој), пре Првог светског рата.
\end{abstract}

Кључне речи: Влашко, печачлбарење.

„Влашко” је реч коју сам чуо у детињству, кад су старине попут мога деде Живка и комшије Живојина, учесника Првог светског рата, који нису постали Солунци јер су рат завршили као заробљеници, кратили зимске ноћи уз пуцкетави огањ у нашој или у комшијиној кући, препричавајући многе догодовштине својих и туђих живота, као да су читали неки велики роман у наставцима. Разуме се, ја онда нисам знао шта је роман, а вероватно нису ни они, али су знали за Влашко и спомињали га кад је требало означити нешто далеко (јер се до тамо одлазило у пролеће, ишло данима, и није се враћало све док не почне снег да пада), нешто другачије (јер су тамо њиве велике, житне, стока безбројна, а газде - бујери), нешто одакле се враћало са жлтицама и „напалијонима” у џепу (ако те успут не пресретну непознанци, и поганци, па те ојаде, на пола пута; да се вратиш - немаш куд, прошла је сезона пољских радова, да идеш кући не смеш - где ти је прошла година, кад ниси ништа спечалио). Из Влашког се нису враћали они најгори, који су морали тамо настрадати од судбине, и они најбољи, које је велики газда с њихове вредноће и поштења или усинио, или узео за зета. У Влашко су људе одводили драгомани, који су газди гарантовали за добре, јаке и поштене раднике, а печалбарима за строге газде који су умели да награде доброг и поштеног слугу.

Одлазак источносрбијанаца, и оних јужније од тога у Влашко, представља облик оновремене сезонске миграције виталног дела мушке популације. ${ }^{2}$ Одлазило се на радове у пољопривреди код бујера („бујер м велепоседник у Влашкој на чијим су поседима радили Тимочани као надничари“ (Динић, 2008: 50). Одвајање од породице, ако се ради о младим људима, а

\footnotetext{
${ }^{1}$ nedb@ni.ac.rs

2 Говорећи о покретљивости становништва Буџака (најзабитијег старопланинског краја, испод самог Миџора, са Калном као административним средиштем, Никола Пантелић каже: „....нарочито су одлазили мушкарци (у 19. и почетком 20. века) на сезонске радове на велика имсња у Румунији.” (Пантелић, 1974, с. 180).
} 
управо о њима је реч, отвара и нека питања поремећаја живота у породици. Растављање младих супружника, момака од девојака, деце од родитеља, рађа нека осећања (туга, брига, страховање...) која су могла наћи одјека и у народним песмама, или у неком другом облику усмене предаје.

Говори о томе, на свој начин, једна печалбарска песма:

Душан драгоманин печалбари збира,

Печалбари збира у Влашко да води,

У Влашко да води паре да печале

Све жлте жлтице, све бели петаци,

Све бели петаџи дома да доносе,

Девојће да просе, млади да се жене.

(Рајковић, 1974: 123)

Наспрам ове дескрипције, има и лирскијих записа, као у песми где мајка буди младо печабарче, јер се већ скупила дружина, „чују се гајде и окање“, „скоро че да појду“, а момче одговара:

Нека појду, нек ме не чекају,[...]

Само, нанче, сьн да си досањам,

У сьн ми је убаво девојче,

Оно оче с'с мене да иде.

(Рајковић, 1974: 123)

Влашко, које је било једина „обећана” земља, јер се пре тога, за времена ропства под Турцима одлазило не у печалбу, већ у ропство или у јаничарство, могло је с јесени опскрбити печалбара очекиваном наградом, али неретко се боравак у томе далеком пределу, куда се одлазило пешке а не железницом или аутом, претаварало у „пусто Влашко далеко“. „Влашко-е Румунија. - Наши стари су ишли у влашко да там работе код бујери. - Идем из тој пусто Влашко!” (Динић, 2008: 75).

Сам термин „Влашко“ са значењем „Влашка зема”, „Земља Влаха” формиран је на исти начин као и за ознаку других земаља према народу који у њима живи, као облик средњега рода придева: „Башта ми бил у ропство у Немачко (= у Немачкој)”, „Добровољци су из Добруџу чак преко Јапан ишли на Солун, преко Бугарско несу могли, пошто Бугари пришли уз Немци”; али и као: „Преко бугарско (= за време бугарске окупације) су учитељи и попови били бугарсћи".

Из влашког се доносила зарада, вероватно увек мања од очекиваног, а још мања од потреба које су се отвориле да се печалбарењем попуне, али су пристизала и нека друга искуства. За нас је значајно да претпоставимо да су се неке речи и изрази досељавали у наша невлашка села управо преко печалбара.

\footnotetext{
${ }^{3}$ У међувремену између научног скупа и појављивања зборника радова са скупа, трагично је настрадао записивач ових стихова др Љубиша Рајковић. Нека овај спомен буде и мала захвалност за све што је учинио на прикупљању народног стваралаштва источне Србије, и за велики Речник тимочког говора, којим је заслужио трајно место у нашој науци.
} 
Да споменемо једно тимочко коло стара влајна, толико раширено да у много варијетета и сад живи све до Сврљишких планина и Нишаве на југу. Коло кокоњеште у сврљишком крају опредељује се као влашко, и зове се кукунеж.

Затим, чуо сам за влашки качамак или мамаљигу.

Вламка помана је пренета као пожељна свечаност, ваљда не зато што је то обичај у славу покојника, већ прилика кад се спремало обилато гошћење, које је слуга могао гледати поиздаље. Кад се детету не свиђа јело које му је припремљено, од старијег је добијало прекор: „А, не ваља ти. Оћеш влашку поману?!” Свакако није смисао „да ти направим подушје“, већ - тражиш ли да ти припремим гозбу?!

Постоји сорта крушака, влавка, за коју се верује да је пренета из Влашке, преко печалбара. Динић наводи „врста крушака из села Влаоле“ (Динић, 2008: 73), што не искључује ни прву помисао. Додуше, и у сврљишком крају постоји село Влава (етн. Влавац, Влавка, кт. влавсћи), али сам чуо да је крушка ипак донета из Румуније.

Два назива за богаташе дуго су била у употреби. Чокоја се пренело на породични назив једне фамиије у Сврљигу, а бујер се некад давала као лични (а онда и породични) прекорни надимак сиротињској, али запуштеној кући, која се звучно лако спајала са значењем „тој су онија што имају млого бује“. Кад се приповедало о богаташима Влашке, ове речи имале су вредност ознаке велепоседника и богаташа уопште, док су пренете на наше услове имале померену вредност у правцу подсмеха, или ироније.

После Другог светског рата кад се одлазило у службу по североисточној Србији, која је словила углавном као „влашки крај”, влашко као да није важило за индустријске градове (Бор, Зајечар, Неготин...), већ само за мања места, руралне провинијенције. Кад се каже, „башта му работи некуде по Влашко", то је назначавало крај, страну, али су градска и познатија места била довољно профилисана да су се именовала својом ојконимском формом, иако су били можда исто толико влашка колико и села око њих. Ипак, дошло је до смене, јер је оно прво Влашко, прекодунавско, замењено причама, легендама, остало у песмама, играма, свиркама у ритму музичких изведби.

Споменућемо још један моменат који није лишен културолошког карактера. Иако немамо података како се осећао наш живаљ (надничари на пољопривредним пословима) у Влашкој, остало нам је чудесно сазнање да су у тренуцима весеља, лагоде, присности, кад је ваљало искорачити из мукотрпног свакодневља, моји земљаци избацили по неку реч или фразу из влашкога говора, а ја сам се чуди откуда они то знају. ${ }^{4}$ Неки су имали и из-

\footnotetext{
${ }^{4}$ Те прве „интерференце“ уочене у детињству, далеко од година кад ћу се бавити језичком науком, сводиле су се на личне појаве: деда Станислав, који је за време Првог светског рата, робовао у Мађарској, псовао је по мађарски, рањеници лечени у Француској, знали
} 
речице. Памтим да су у колу неки узвикивали ,,аша биње”, да је деда Јанко своје другаре звао „мошуље”, да су другари у шали један другом псовали ,бьлгьзу".

Прилог:

\author{
Матеја Васић, добровољац \\ из Јаловик Извора, рођен 1900.
}

Девесто шеснајсте сам служил као дечак код бојера*. И тамо ме затекал рат. И кад је почела наша добровољачка дивизија, у Русију, да се образује, дошал један поднаредник и казал: „Ко је Србин и мисли за српство, слободно нека пође са мном, идемо у Букурешту, у нас конзулат, да добијемо упут за Русију, за наше добровољачке јединице”... Онда напустимо газду, отидемо право у Букурешту, у наш конзулат добијемо упут, и одатле бесплатно смо се возили, и возом, и лађом. и отидемо за Русију.

Кад смо дошли у велику варош, звану Одеса, дочекаше нас наши официри, туј се наша војска образувала, и туј смо се обукли у војничко, нема више цивила. Туј смо се подучили с ону стару војску, ал је та војска сва пречанска војска била, из Баната, из Лике, из Босне. То су били аустријски војници, у борби против Русију, па су допали ропство у Русију. И било питање код њи: „Кој жели да буде добровољац, за Србију, да се бори за своју отаџбину, за своји домове, нека излази у добровољачки одред, а кој не воли, нек остане у ропство."

И они - сви српски говоре, кој не жели српство - све се то пријавило у добровољце. Наши официри су и’ подучили; после тога смо били у борби, у Добруџи, против Турци, и против Бугари. Немачка је њина странка била. А кад смо ми били у Добруџи, тегај је Коста Пећанац подиго устанак у Србију, да побуни мало непријатеља, да ми можемо да успемо, да дођемо овам, из Добруџе, преко Бугарску. Али беше велика турска и бугарска и немачка сила у Добруџи. Туј су платили животом јадни наши, шест иљади изгинуло, од осамнајес иљади смо се вратили само дванајес иљади у Русију.

Из књиге Владете Р. Кошутића: Пастирења (у штампи). ${ }^{5}$

\footnotetext{
су: бонжур, и још по нешто, мој отац и други сељани заробљеници из Другог светског рата, јели су шпек и пили шнапс, а један млађи рођак, још жив, који је служио војску у Мостару и данданас говори прије, уместо пре. Нисмо много одмакли у учењу страних језика, тек толико да макар у једној речи нисмо као околина.

${ }^{5}$ Имао сам ту част да припремим књигу записа разговора са Солунцима (борцима Првог светског рата) Док су Солунии још говорили, Чигоја штампа, Београд, 2011. Та књига садржала је разговоре проф. Владете Кошутића са старинама сврљишког и сокобањског краја, али је у професоровој заоставштини био и део о Солунцима из Буџака, подно Старе планине, одакле је узет и овај одломак.
} 


\section{Литература}

Кошутић, 2011: В. Р. Кошутић: Пастирења (у штампи). Један део, под насловом Док су Солунии још говорили, прир. Н. Богдановић, објавила је Чигоја штампа, Београд.

Пантелић, 1974: Н. Пантелић: Етнографске белешке из Буџака; Гласник Етнографског музеја у Београду, књ. 37, Београд.

Рајковић, 2016: Љ. Рајковић Кожељац: Антологија усменог песништва источне и јужне Србије, Лексика, Неготин.

Nedeljko R. Bogdanović

\section{VLAŠKO IN ORAL TRADITION}

\section{Summary}

The paper points out the rare remnants of memories of people from the border of eastern Serbia working on large estates in Romania (Wallachia), before the First World War.

Keywords: Wallachian, printing. 